\title{
Achievement Motivation as Antecedents of Quality Improvement of Organizational Human Resources
}

\author{
Any Werdhiastutie ${ }^{1}$, Fendy Suhariadi ${ }^{2}$, Sri Gunani Partiwi ${ }^{3}$ \\ ${ }^{1}$ Post Graduate School Airlangga University Surabaya \\ ${ }^{2}$ Faculty of Psychology Airlangga University Surabaya \\ ${ }^{3}$ Faculty of Industrial Technology Institute of Technology Sepuluh Nopember Surabaya \\ any-w11@pasca.unair.ac.id
}

\begin{abstract}
Achievement motivation is closely related to success and success or individual spirit in achieving a goal or success. David McClelland is famous for the theory of the need to achieve achievement that states that motivation varies, according to the strength of one's need for achievement. Motivation of work is a strong desire for humans to do a job related to the goals and needs to be achieved. Achievement motivation should also be designed according to the strategy model. Analysis of achievement motivation will lead to the form of evaluation on human resources and other potentials owned by the organization appropriately. Achievement motivation is intended to encourage the elements of improvement that will be applied and evaluated as the stage of improving the quality of human resources organization. Individual needs are met able to improve performance. Individuals in this study are motivated on the basis of achievement to be achieved based on the needs of each individual. Achievement motivation implanted in work system according to individual needs and desires is found able to produce greater individual performance improvement
\end{abstract}

Keywords

achievement motivation; quality of human research; motivation

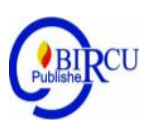

\section{Introduction}

The term of need for achievement was first popularized by Mc Clelland as a mental virus. This mental virus is associated with a thought related to how to do things well, faster, more efficient than what was done before (Weiner, 1985). Achievement motivation is often seen as an encouragement in achieving success in an organization. Achievement motivation is instilled in the individual in order to be able to master, manipulate and regulate the social and physical environment to achieve a high work quality improvement by competing through business beyond the results of previous work. The process of planting a mindset of achievement motivation to improve personal skills as high as possible in all activities. Achievement motivation is a motive to encourage individuals to achieve success to aim for success in competition with several measures of excellence, measures of excellence are used for the standards of achievement of self-achieved achievement before and are feasible to gain a competency. 
Human resource development is an effort to develop the quality or ability of human resources through the process of planning education, training and management of personnel or employees to achieve an optimal result (Notoatmodjo in sulasmi, 2020). The development of human resources through the cultivation of achievement motivation is one of the contributions in improving the quality of human resources.

The development of human resources should focus more on increasing productivity and efficiency. This can be realized because today's competition, especially among nations, is getting tougher and demands the quality of strong human resources as managers and implementers in an organization or institution. Therefore, HR development is directed so that it is truly capable and has a productive, creative, and disciplined work ethic. Besides that, it is also able to utilize, develop and master the knowledge and technology that are needed to achieve optimal performance (Sitepu, 2014).

Although this definition of Human Resource Development is defined differently in several countries or in an international perspective, it has an understanding of the same basic concepts. This is effected because of different interpretations and roles within every State. In the beginning there was an understanding that development was identical to training, which could be understood as a form of understanding in terms of the types of activities carried out in several organizations. But in the development process, people begin to understand the development of human resources more than training, which is integrated with career development and organization to develop the effectiveness of individuals and organizations (Dipang, 2013).

The implementation of human resource development must be well planned to get satisfactory results and as expected. Before development is carried out, an analysis needs to be done to find out the types and methods of development needed by employees. To find out whether the obtained results are in accordance with the objectives, it is necessary to evaluate the implementation of human resource development, because with careful planning, it is expected that the implementation of human resource development can run in accordance with the objectives that want to be achieved by the company (Dipang, 2013). In order that this doesn't become a problem in the future. Human resource development should be very closely related to organizational change. Many scientists emphasize the importance of a vision about readiness for organizational change and organizational growth (Haque, Titi, \& Liu, 2016). The relevant social context determines which categorization seems most suitable to provide a meaningful organization (Saragih et al 2019).

Motivation factor especially in achievement motivation is one of the things that drives and supports the improvement of the quality of the organization's human resources. Understanding of achievement motivation in individuals can help improve performance both directly and indirectly. Achievement motivation raises hope so that it is able to manage the mindset to create work ethics and values that exist in the organization.

\section{Review of Literature}

Larsen and Buss (2005) explained that achievement motivation is defined as the desire to do the best, be successful and feel capable or do competence. Achievement motivation is assumed capable of encouraging and give exist and appropiate certain energy. Achievement motivation can encourage job satisfaction where individuals who work without achievement, the individual is not satisfied with the results of work. JW Santrock (2003) explained that 
achievement motivation creates a desire to finish things based on the standards of success and doing business with the aim of achieving success.

According to Atkinson (1997) explained that individual achievement motivation is based on two things, namely the tendency to achieve success and tendency to avoid failure. Individuals have a tendency to achieve strong success means having the motivation to achieve success that is stronger than the motive to avoid failure and responsiveness in various situations.

Achievement motivation is very closely related to success or individual enthusiasm in achieving a goal or success. David McClelland is famous for the theory of the need to achieve achievement which states that motivation varies, according to the strength of one's needs for achievement. McClelland's achievement motivation was said by McClelland as a power in human mentality to do an activity that is better, faster, more effective and more efficient than previous activities (Sobur, 2003).

According to McClelland (1971) in Wijono (2010) suggested that there are three dimensions of motives, namely motives of power, affiliation and achievement. Power motives can be shown in positive or negative terms. Affiliate motives are found in two forms, namely affiliative guarantees and affiliative interests. Individuals have a high affiliate guarantee motive always anticipating the feelings and views of people who are under him or her both towards themselves or the task. Achievement motives are applied by individuals by doing things diligently and work risk is moderate so that the individual will succeed in being responsible and obtain feedback on the results of achievement. Achievement motives lead to future interests compared to the past or future and individuals will be stronger in facing failure because in the individuals they can predict future situations to get better performance in work..

Wuryani (2008) argued that achievement motivation can be divided into two namely autonomous achievement motivation and social achievement motivation. Achievement motivation that has characteristic of autonomous is based on self-existing standards, namely achievements that have been achieved before. Achievement motivation that has characteristic of social is based on comparisons that come from outside the achievements of others.

Factors that influence achievement motivation according to Fernald and Fernald (1999) in Rola (2006) namely:

1. The influence of family and culture where the amount of freedom that parents give their children. The type of work of parents and the number and sequence of children in a family have a very large influence in the development of achievement motivation.

2. The role of self-concept. Self-concept is the way of individuals to think about themselves. If an individual believes that he/ she is capable of doing something, the individual will be motivated to do something so that it influences him/ her in behaving.

3. The influence of gender roles. High achievement is usually identified with masculinity so that it affects women's self-confidence when studying. Women tend to feel afraid of showing achievement when in a male environment.

4. Recognition and achievement where individuals will be motivated to work hard if they feel cared for by the environment.

MAccording to Murray in Alwisol (2009) explained that the characteristics of individuals who have and apply achievement motivation are more competitive, more responsible for personal success, happy to set challenging goals but still be realistic, have assignments with sufficient difficulty levels which have been measured the level of capability of completing, happy with risky work according to ability, refusing routine work and being proud of the achievements and not quickly feeling satisfied so that they always rearrange the 
next achievement target. Human resources who have high achievement motivation tend to have fairly good thinking and physical abilities.

Human resources are integrated capabilities of the mind and physical power possessed by individuals. Human resources are seen as capabilities possessed by humans to be utilized to run an organization or business so that it is efficient or successful. This means that humans have abilities that need to be developed to achieve planned goals and objectives. Further explained that "development is an effort to improve the technical, theoretical, conceptual, and moral capabilities of employees in accordance with the needs of work / position through education and training.

Human resource development is an effort to develop the quality or ability of human resources through the process of education planning, training and management of personnel or employees to achieve an optimal outcome. The development of human resources is a process of changing the human resources who belong to an organization, from one situation to another, which is better to prepare a future responsibility in achieving organizational goals. Development refers to the problem of staff and personnel is a long-term educational process using a systematic and organized procedure by which managers learn conceptual and theoretical knowledge for general purposes.

Human resources development is defined as a series of systematic and planned activities designed by the organization to provide opportunities for its members to learn needed skills to meet current and future work requirements (Mc Guire,2014:121). Human emphasis both as a tool and as a final goal of development. In the short term, it can be interpreted as the development of education and training to meet immediately the technical experts, leadership, administrative staff. The definition above places humans as actors and recipients of development. The action that needs to be done in the short term is to provide education and training to meet the needs of skilled employees.

Human resources of an organization that has high achievement motivation tend to prefer to struggle with activities that have moderate challenges. Human resources in organizations with this mindset are always motivated to be better and even better than others. Personal tasks with personal responsibility are often given by the organization in order to improve the personal abilities of individuals so that they can grow their potential. Giving assignments with this personal responsibility then produces feedback on various things done. The results of the feedback are used as material for evaluation of the tasks previously that's done.

\section{Discussion}

\subsection{Improving the Quality of Human Resources Based on the Application of Achievement Motivation}

Every organization needs resources to achieve a determined effort (Dew, 2009). Human resources are one of the important factors that are constantly being discussed. Therefore more efforts are needed to build human development as a workforce. Organizations must be able to manage and utilize in such a way so that the potential of human resources in the organization can be developed. Dew's (2009) research offered a model by looking at the creativity potential of innovators, both intrinsically and extrinsically. Creative human resources greatly help organizational change. So, organizations need to identify human resources that have intrinsic and extrinsic creativity (Dew, 2009). This will then strongly support the pattern of change regularly and can also increase the motivation of individual and group work.

Human resources development, especially in order to improve the quality of organizational resources, give the organization benefits. Ability, potential and right 
experience can improve understanding of concepts, information contexts, opinion development, capacity building to carry out tasks. The process of division of tasks is known to be adapted to individuals who have the expertise, knowledge and possessed attitude. The progress that belongs to the organization can be created with the additional of developing human resource capabilities enhancement. The Enhancement of human resources capabilities are carried out not only in technical, expertise and knowledge. Another thing that was developed except on technical orientation of the work namely the quality of decision making, ethical values and goals motivation in work.

Work motivation is a strong desire for humans to do a job related to the goals and needs which they want to achieve. Gibson (1995) stated that there is factor except the work environment that can drive the level of motivation, namely: job content that will drive the level of motivation so that it can produce good performance. These intrinsic conditions include achievement, recognition, responsibility, advancement, the work itself and the possibility of growth (Sumantri, 2016).

Basically, the organization must have a good strategy, so as to increase achievement motivation. Achievement motivation must also be designed according to the strategy model. Analysis of achievement motivation will lead to from of the evaluation of human resources and other potentials that the organization possesses appropriately. The referred achievement motivation encourages the improvement elements that will be applied and evaluated as a step in improving the quality of the organization's human resources.

According to Paul and Don David (2015) in research about three theories of general needs and their relationships. According to Maslow's theory, there is a hierarchy for needs where basic needs that cannot be fulfilled, then the next needs cannot be fulfilled. This opinion is the opposite of the Alferder's theory where other needs can be met without having to fulfill basic needs first so there is no hierarchy of needs to increase productivity. McClelland used Maslow's theory to show that individual experiences and environmental conditions determine productivity. Two individual productivities in this study showed significant results where interest in individual condition which was supported by achievement motivation then had an impact on the behavior of high individual performance. Taylor emphasized that the best way to increase productivity was by providing an understanding of the organization, the system on the basis of different individual needs. Individual needs that were met could improve performance. Individuals in this study were motivated on the basis of the achievements to be achieved based on the needs of each individual. Achievement motivation that was instilled in the work system according to individual needs and desires was found to be able to produce greater individual performance improvements.

The next study was Moore, Dustin and Craig (2010) explained that the studied students were found to get motivation to achieve and participate in leadership learning. Needs that want to be fulfilled are recognition so that encouraged to make achievements. The need to develop knowledge, skills and abilities. This study examined students motivation in participating using the theory of achievement motivation. The results showed that McClelland's achievement motivation theory was a driving factor and booster in learning something in order to be additional of knowledge, competence and capability. The next impact was that by the existence of the knowledge that was possessed, competencies and capabilities increased, the personal qualities increased.

\section{Conclusion}

Development of motivation to realize the improvement of human resources quality which appropriate with individual needs would direct the quality of the organization to a 
better direction, and could increase the motivation of individuals work and groups in an organization. Moreover, the comfortable organizational system and suitable with the identity of employees, so it could be ascertained that achievement motivation would lead to improve the quality of the organization's human resources.

Thought that has been described by the author can be considered as a recommendation for the shortcomings of the theories above, namely improving the quality of human resources based on achievement motivation. In order that the organization pay attention to the used organizational model, so that it is adjusted to the organization's identity and the desired vision and mission of change.

As for the requirements of the organizational model can be started from examining the differential pattern of employee attitudes towards the organization before and after the changes are implemented. Then pay attention to the needs of the development of organizational human resources through achievement motivation as an efforts to develop the organization in the long term. From seeing the differential pattern, it is hoped that it will shape appropriate work motivation with the improvement of the quality of human resources.

\section{References}

Alwisol.(2009).Psikologi Kepribadian Edi Revisi.Malang:UMM Press

Atkinson.(1997).Pengantar Psikologi Edisi Kedepalan Jilid I.Jakarta:Erlangga

Dew, R. (2009). Creative Resolve Response: How Changes in Creative Motivation Relate to Cognitive Style. Journal of Management Development, Vol. 28 Iss 10, 945-966.

Dipang, L. (2013). Pengembangan Sumber Daya Manusia dalam Meningkatkan Kinerja Karyawan Pada PT. Hasjrat Abadi Manado. Jurnal EMBA Vol.1 No.3 September, 1080-1088.

Fernald LD \& Fernald, Peter.(1999).Introduction to Psychology.India:AITBS Publisers \& Distribution.

Haque, M., Titi, A., \& Liu, A. L. (2016). The Role of Vision in Organizational Readiness for Change and Growth. Leadership \& Organization Development Journal, Vol. 37 Iss 7.

Larsen RJ \& Buss DM.(2005).Personality Psychology: Domains of Knowledge About Human Nature.Boston : Mc Graw Hill

Mc Guire, David. (2014).Human Resources Development Second Edition.Los Angeles:SAGE

McClelland et al. (1971).The Achievement Society.New York:New Jerseyn Van Nostrand Reinhold

Moore L,L.Dustin,Craig.(2010).using Achievement Motivation Theory to Explain Student Participation in a Residential Leadership Learning Community.Journal if Leadership Education Vol 9 Issue 2

Paul dan Don.(2015).Needs Theory and Employee Performance: A Case Study of Employed PNG University Graduates.

Rola F.(2006).Hubungan Konsep Diri Dengan Motivasi Berprestasi Pada Remaja.Fakultas Psikologi USU:Medan

Santrock JW.(2003).Adolescence : Perkembangan Remaja.Jakarta:Erlangga

Saragih, Hisarma et al. 2019. The struggle of Batak Simalungun for their identity in Church organization in Simalungun, Medan, Indonesia. Journal of Human Behavior in the Social Environment, 693-704.

Sitepu, I. U. (2014). Manajemen dan Keterampilan Kinerja Pegawai Pada Asuransi Jiwa xxx. Jurnal Saintech Vol. 06-No. 2- Juni, 54-58. 